\title{
Kinematics parameters of twosectional trencher's
}

\author{
Mykhailo Sukach, Sergij Lysak \\ Київський національний університет будівництва і архітектури \\ Повітрофлотський просп., 31, Київ, Україна, 03680 \\ msukach@ua.fm, orcid.org/0000-0003-0485-4073
}

Summary. The analyses of working process of trencher that fully uncovers the pipeline along its perimeter, was made. Interrelations between kinematic and geometric parameters of the working equipment were defined.

Key words: kinematic analysis, trencher, pipeline, working equipment.

\section{INTRODUCTION}

Reliability of Ukraine's pipelines transportation is a very important indicator of stability of supplying Western European countries with fuel and energy resources. Taking into account that pipelines system was built most actively in $1960-80$ years, most of them are operating with significant exceed of service life. This results in pipeline's operating safety decrease, which depends on timely and high quality overhaul [1...5].

Pipeline's operational reliability significantly depends on insulating coating corrosion, that appears due to intensive aging process. This usually leads to frequent accidents and stoppages of oil transferring to consumers [6-8].

New major repairs technology enables renewal of pipeline's efficiency without lifting pipe from the ground trench along the full length of repaired area $[9,10]$. This repair is carried out by using a set of technologically connected special earthmoving machines
(Fig.1). One of them is a chain trencher, which opens the pipeline in a trench. The authors are presenting the adapted working equipment, which allows to fully uncover the pipeline along its perimeter, excluding at that the machine for digging under the pipe. Modernization of machine requires proper scientific basis of constructive and kinematic parameters of the working equipment, therefore addressing these problems is important $[11,12]$.

\section{PURPOSE OF THE WORK}

The purpose of the work is a kinematic analysis of the working process of a trencher that uncovers and simultaneously undermines the trunk pipeline.

\section{THE MAIN RESULTS OF THE WORK}

The trencher construction (Fig.2) proposed by the Authors consists of the base machine 1, which moves along the pipeline 2 and the working equipment $3[13,14]$. Soil is worked and transported by chain sections 4,5 . Then the ground moved from the trench is evacuated by the conveyor 6 . Equipment is operated by hydraulic cylinders $7,8,9$. Controlling of the machine along the pipeline is done by tracking devices 10 . 

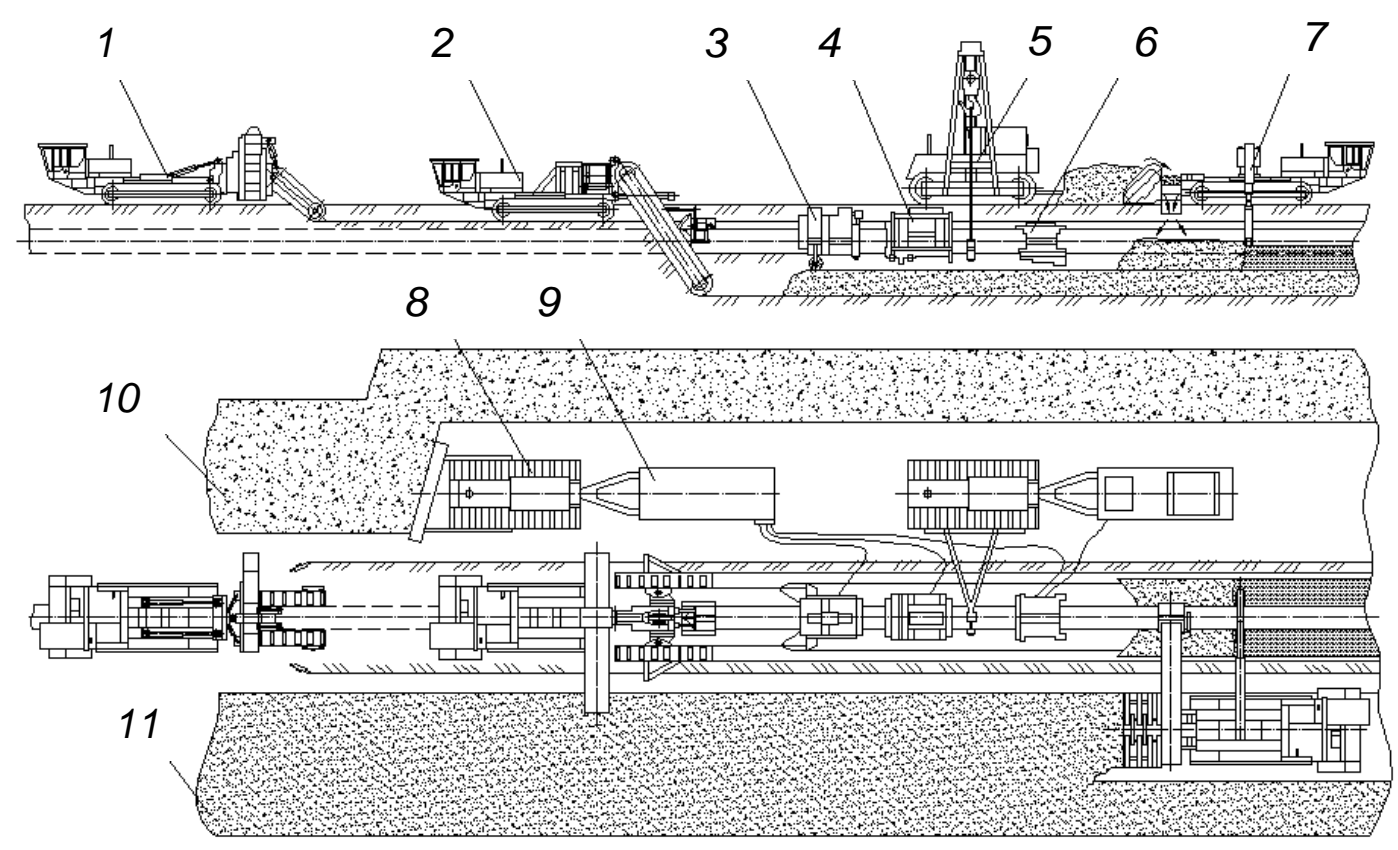

Fig.1. Technology of pipelines overhaul: 1 - machine of digging the ground by layers; 2 - pipeline uncovering machine; 3 - pipeline undermining machine; 4 - isolation removal machine; 5 - pipes-laying machine; 6 - isolation putting machine; 7 - machine for soil compaction; 8 - bulldozer; 9 - diesel power station; 10 - fertile ground; 11 - mineral soil

In regime of pipeline uncovering by twosectional chain trencher, the working pocess represents the combination of two motions: motion of a chain with fixed on it cutting tool at velocity of $v_{\mathrm{c}}$; progressive motion of the base machine along the pipeline during a trench digging at velocity of $v_{\mathrm{M}}$.

Thus, cutting tool performs a complex motion: together with the chain, it moves with respect to the machine and together with machine - with respect to the soil (bottom hole) [15].

1. Let's consider the kinematics of motion of a prototype-machine's working tool, with chain sections installed in parallel to each other (without undermining the pipe).

While making uncovering of underground pipeline with chain sections installed in parallel to each other, the machine is working in the mode of longitudinal digging excavator, when the plane of motion of the working tool's chains is in the same plane (or in parallel) with the main machine's motion.
Kinematic feature is in the cutting tool's motion trajectory deviation by angle A (Figs.3, 4), which is less than the tilt angle of working tool's carcass with respect to the bottom hole $\beta$ [16]:

$$
\operatorname{tg} \alpha=\frac{v_{\mathrm{C}} \sin \beta}{v_{\mathrm{C}} \cos \beta+v_{\mathrm{M}}} .
$$

Analysis of this dependence demonstrates that the angle of deviation of cutting trajectory mainly depends on the angle of installation of the working tool's carcass and driving chain's velocity, as the machine's motion velocity is a relatively small amount.

As the chain sections are fixed at different angles to the bottom of the trench in order to cross the vertical axis of the trench during the pipes undermining (see Fig.2), the cutting tool trajectory deviation angles for each section will be different [17]. Let's fix the tilting angle to the bottom hole for one section (for example the right one) $\beta_{1}$ (usually it is about $60^{\circ}$ ). 


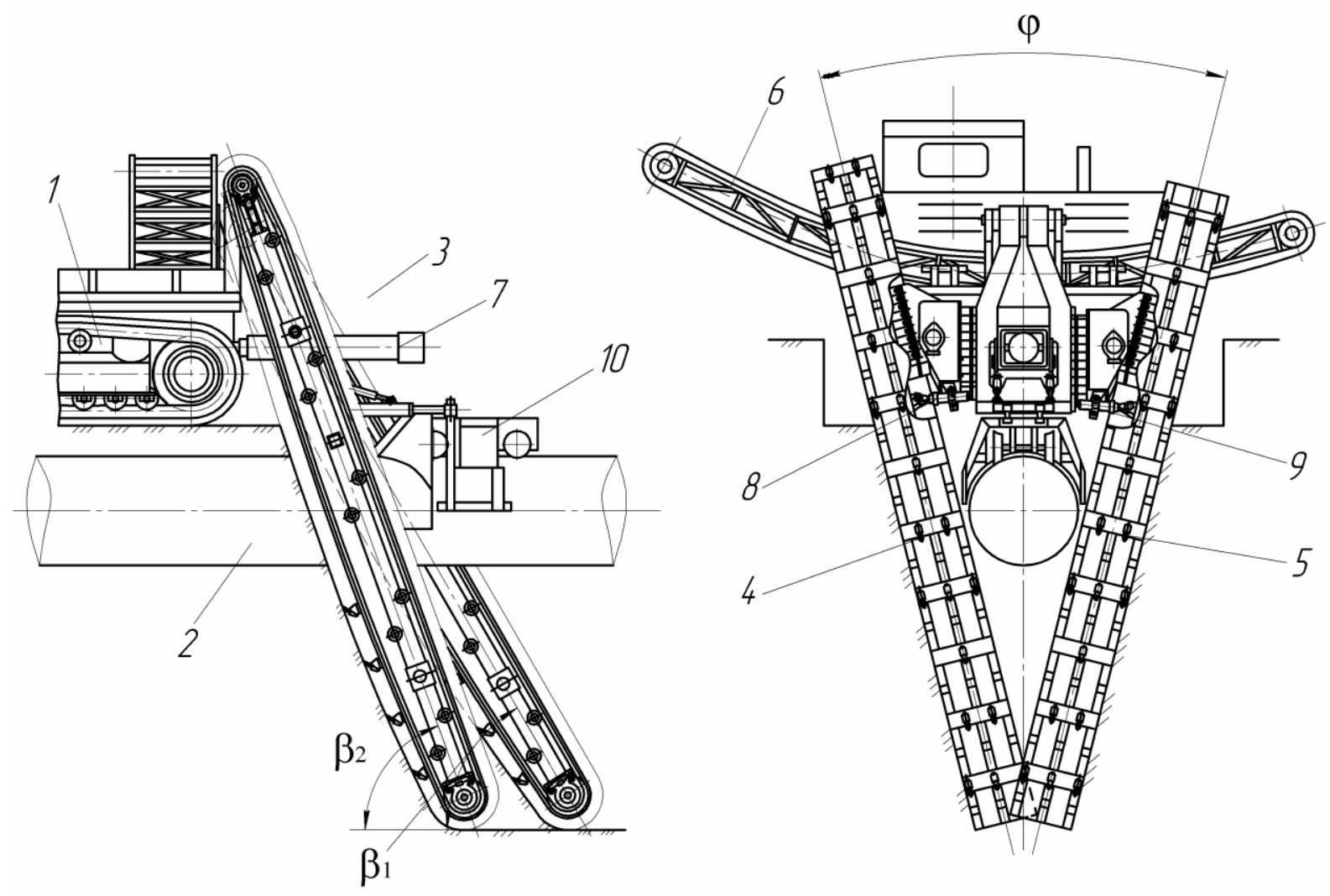

Fig.2. Chain trencher: 1 - base machine; 2 - pipeline; 3 - working equipment; 4, 5 - chain section; 6 - conveyor; 7 - 9 - hydraulic cylinders; 10 - control devices

Then, taking this into account, deviation of the cutting tool motion trajectory for the right sections will make up

$$
\operatorname{tg} \alpha_{1}=\frac{v_{\mathrm{c} 1} \sin \beta_{1}}{v_{\mathrm{c} 1} \cos \beta_{1}+v_{\mathrm{M}}},
$$

where $v_{\mathrm{Cl}}-$ the working tool's right section chain motion velocity; $v_{\mathrm{M}}-$ base machine motion velocity, or

$$
\alpha_{1}=\operatorname{arctg} \frac{v_{\mathrm{c} 1} \sin \beta_{1}}{v_{\mathrm{c} 1} \cos \beta_{1}+v_{\mathrm{M}}} .
$$

For the left section, taking into account the fact that it is fixed at an angle $\beta_{2}$, will make up

$$
\operatorname{tg} \alpha_{2}=\frac{v_{\mathrm{c} 2} \sin \beta_{2}}{v_{\mathrm{c} 2} \cos \beta_{2}+v_{\mathrm{M}}},
$$

or

$$
\alpha_{2}=\operatorname{arctg} \frac{v_{\mathrm{c} 2} \sin \beta_{2}}{v_{\mathrm{c} 2} \cos \beta_{2}+v_{\mathrm{M}}},
$$

where $v_{\mathrm{C} 2}-$ the working tool's left section chain motion velocity;

The obtained formulas connect base machine motion velocity $v_{\mathrm{M}}$ and kinematic parameters of the relevant chain sections motion.

The parameters of the chips that are removed by the cutting instrument during machine's operation are their length and width. The width of the chip depends on the geometrical parameters of the working tool, therefore its value is not calculated but is obtained basing on the working tool parameters.

Taking into consideration the kinematic parameters of the machine's velocity (see Fig.3), the chip thickness $h_{2}$ for the left section of the working tool of $h_{2}=s_{2} \sin \alpha_{2}$, where $s_{2}-$ 


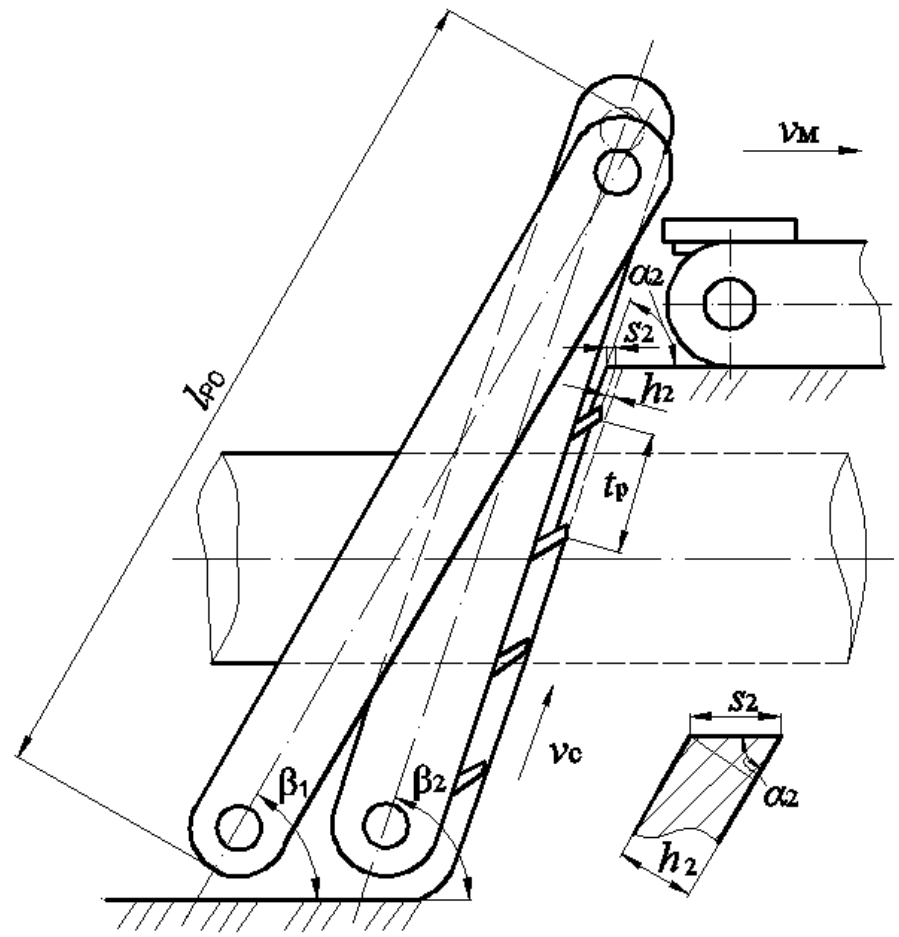

Fig. 3. Scheme of motion of the cutting bits of working tool's chain sections

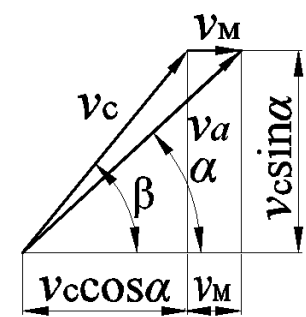

Fig.4. Scheme of the chain working tool's velocity with the sections fixed in parallel feeding for one girder with cutting bits of the left section (or the distance that is passed by the trencher for the time of coming out from the bottom hole of two successive girders). Similarly define the thickness of the chip $h_{l}$ for the right section of the working tool: $h_{1}=s_{1} \sin \alpha_{1}$, where $s_{1}$ - feeding for one girder with cutting bits of the right section.

Taking into account that base machine's motion velocity is a relatively small value in comparison to the chain's motion velocity, i.e. $v_{\mathrm{M}}<<v_{\mathrm{I}}$, you can assume that angles $\beta \approx \alpha$, i.e. the soil cutting velocity corresponds approximately to the velocity of the chain of the corresponding section of the working tool. Therefore, we can write down:

$$
h_{1}=s_{1} \sin \beta_{1}, h_{2}=s_{2} \sin \beta_{2} \text {. }
$$

Conveying of the cutting bits for the left and right sections will be

$$
s_{1}=t_{\mathrm{p}} \frac{v_{\mathrm{M}}}{v_{\mathrm{c} 1}}, s_{2}=t_{\mathrm{p}} \frac{v_{\mathrm{M}}}{v_{\mathrm{c} 2}},
$$

where $t_{\mathrm{p}}-$ cutting bits layout pitch in the line of cutting. Taking into account these formulas, the thickness of the chip

$$
h_{1}=t_{\mathrm{p}} \frac{v_{\mathrm{M}}}{v_{\mathrm{c} 1}} \sin \beta_{1}, h_{2}=t_{\mathrm{p}} \frac{v_{\mathrm{M}}}{v_{\mathrm{c} 2}} \sin \beta_{2} .
$$

Analyzing the latter formulas one can conclude that changing the motion parameters of base machine $v_{\mathrm{M}}$ and of chain $v_{\mathrm{C}}$ it is possible to adjust the thickness of the chip that is being cut $h$ at the constant constructive and kinematic parameters of the working tool $t_{\mathrm{p}} \mathrm{i} \beta$. For a smooth adjustment of values $v_{\mathrm{M}}$ and $v_{\mathrm{c}}$ it is necessary to apply an adjustable hydraulic drive, because manual transmission, even with a significant number of gears, assumes the discreteness of change of these parameters.

Thus, we obtained the values of chain sections motion velocity parameters and values of soil chips parameters, which are cut at chain sections being fixed in parallel.

2. Let's consider now the kinematics of working tool motion during the process of digging under the pipeline, i.e. when the chain 
sections are set to each other at an acute angle $\varphi$ (Fig.5). At that the kinematics of the process is changing, what affects the working progress of the machines on the whole.

Absolute velocity $v_{a}$ vector equation looks (see Fig. 5) $\bar{v}_{a}=\bar{v}_{\mathrm{c}}+\bar{v}_{\mathrm{M}}$, where $\bar{v}_{\mathrm{C}}-$ the velocity vector of the chain motion in the corresponding section of the working tool; $\bar{v}_{\mathrm{M}}-\mathrm{ve}$ locity vector of base machine motion during the trench digging.

As an example, let's consider the kinematics of motion of the left chain section of working tool. We have the spatial (three dimensional) coordinate system with coordinate axes $x, y, z$, point $O$ - coordinate basic origin. Chains velocity $v_{\mathrm{C}}$ (and hence the plane of motion) will deviate from the plane of motion of the base machine by the angle $\varphi / 2$, which provides crossing the vertical axis of the trench with lower parts of the working tool's sections. Velocity $v_{\mathrm{C}}$ is directed at an angle $\beta$ to the plane $x z$ (the plane of the bottom of the trench), which equals the angle at which the working tool's chain section carcass is fixed (installed).

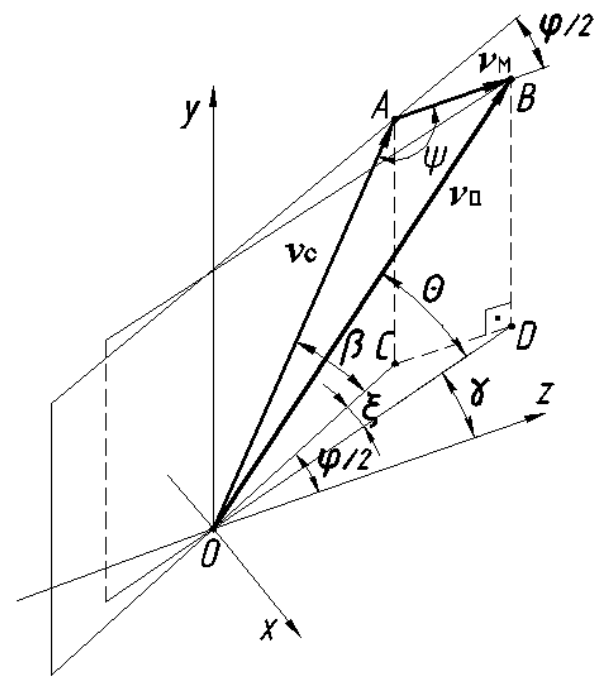

Fig.5. Scheme of the chain working tool velocity during the pipeline undermining (sapping)
Plane of the machines velocity vector $v_{\mathrm{M}}$ is in parallel to the plane (axis) of the tractor's velocity motion $y z$. Thus, we come to the absolute velocity of soil cutting $v_{a}$. Vector $v_{a}$ is in the plane which deviates from the plane of tractor's motion at an angle $\gamma$ and is at an angle $\theta$ to the horizontal plane $x z$ (plane of the bottom hole).

Let's define the parameters $v_{a}, \theta, \gamma$, for that let's consider the triangle $\triangle O A B$, in which the sides $O A=v_{\mathrm{C}}, A B=v_{\mathrm{M}}$, the angle between them $\psi=180^{\circ}-\varphi / 2$. According to the theorem of cosines

$$
v_{a}=\sqrt{v_{\mathrm{c}}^{2}+v_{\mathrm{M}}^{2}-2 v_{\mathrm{c}} v_{\mathrm{M}} \cos \left(180^{0}-\varphi / 2\right)} .
$$

In triangle $\triangle B D O$ :

$$
\sin \theta=\frac{B D}{O B},
$$

where $B D=A C=O A \sin \beta$.

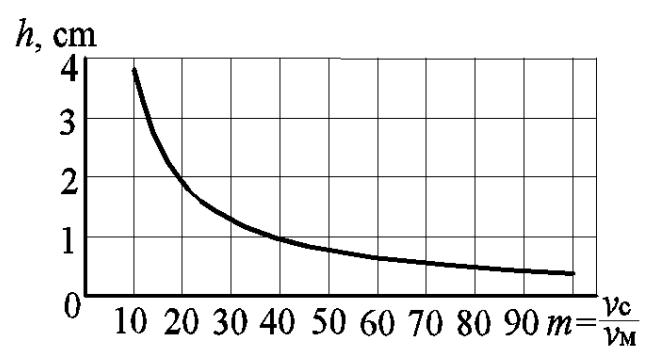

Fig.6. Dependence of chips thickness on constructively-kinematic parameters of working process 
Taking into account that $O B=v_{a}, O A=v_{\mathrm{C}}$, we come to $\sin \theta=\frac{v_{a}}{v_{\mathrm{c}} \sin \beta}$, or

$$
\theta=\arcsin \frac{\sqrt{v_{\mathrm{c}}{ }^{2}+v_{\mathrm{v}}{ }^{2}-2 v_{\mathrm{c}} v_{\mathrm{v}} \cos \left(180^{0}-\varphi / 2\right)}}{v_{\mathrm{c}} \sin \beta} .
$$

The obtained dependence combines parameters of motion velocities of the working tool $v_{\mathrm{C}}$, of base machine $v_{\mathrm{M}}$ and of angles of chain sections carcass fixing to the horizontal plane of the bottom hole $\beta$ and its rotation $\varphi / 2$ for pipeline undermining.

Angle $\gamma$ of deviation of the plane of soil cutting absolute velocity $v_{a}$ from the tractor's motion plane $y z$ according to Fig. 5 $\gamma=\varphi / 2-\xi$, where $\xi-$ the angle between the horizontal projections of the absolute velocity of cutting $v_{a}$ and chain motion velocity $v_{\mathrm{C}}$. In a triangle $\triangle C O D$ :

side

$$
\begin{aligned}
& O C=O A \cos \beta, \\
& O D=O B \cos \theta, \\
& C D=A B=v_{\mathrm{M}} .
\end{aligned}
$$

Replacing the corresponding sides of the triangle $\triangle C O D$ by horizontal projections of the velocities we obtain

$$
\cos \xi=\frac{v_{\mathrm{M}}^{2}-v_{a}{ }^{2} \cos ^{2} \theta-v_{\mathrm{c}}{ }^{2} \cos ^{2} \beta}{2 v_{\mathrm{c}} \cos \beta v_{a} \cos \theta},
$$

or

$$
\xi=\arccos \frac{v_{\mathrm{M}}^{2}-v_{a}{ }^{2} \cos ^{2} \theta-v_{\mathrm{c}}{ }^{2} \cos ^{2} \beta}{2 v_{\mathrm{c}} \cos \beta v_{a} \cos \theta} .
$$

Then angle

$$
\gamma=\varphi / 2-\arccos \frac{v_{\mathrm{M}}{ }^{2}-v_{a}{ }^{2} \cos ^{2} \theta-v_{\mathrm{C}}{ }^{2} \cos ^{2} \beta}{2 v_{\mathrm{c}} \cos \beta v_{a} \cos \theta} .
$$

From the last formulas follows that the thickness of chip that is being cut by the chain sections during the pipes undermining, is

$$
h_{1}=t_{\mathrm{p}} \frac{v_{\mathrm{M}}}{v_{\mathrm{c} 1}} \sin \theta_{1} ; h_{2}=t_{\mathrm{p}} \frac{v_{\mathrm{M}}}{v_{\mathrm{c} 2}} \sin \theta_{2} .
$$

Motion velocity of trench excavator's chain usually equals $v_{\mathrm{C}}=0,4 \ldots 2 \mathrm{~m} / \mathrm{s}$, and the machine's motion velocity during the pipeline undermining is $v_{\mathrm{M}}=80 \mathrm{~m} / \mathrm{h} \quad\left(v_{\mathrm{M}}=0,022\right.$ $\mathrm{m} / \mathrm{s})$. Graph on fig. 6 shows the dependence of the thickness of soil chip that is being cut on the constructive (cutting bits layout pitch, angle of carcass fixing) and kinematic (chain and machine's motion velocity) parameters of the process.

According to the graphic interpretation of the above dependency, as the chain's motion velocity increases, at machine's motion velocity being constant, the soils chips thickness decreases. At ratio $m=\frac{v_{\mathrm{C}}}{v_{\mathrm{M}}}=10 . . .50$ the rapid reduction of chips thickness is observed, and at velocities ratio $m=60 \ldots 100$ this value has no significant change of parameter $h$. Therefore, in this range the change of chain velocity is inexpedient.

\section{CONCLUSIONS}

1. In result of machine's working process kinematic analysis it was established that the cutting bits motion trajectory $\alpha$ deviates from the working equipment's carcass fixing angle $\beta$.

2. The dependencies were obtained, which interrelate the geometric and kinematic parameters of the soil digging process, namely: the thickness of chips $h$, sections fixing angles towards the bottom hole $\xi, \gamma, \varphi$, cutting bits layout pitch $t_{\mathrm{p}}$ and other.

3. Basing on these dependencies one can define and regulate the motion velocity of chain $v_{\mathrm{C}}$ and machine $v_{\mathrm{M}}$ to provide the necessary thickness of the soil chips $h$, that are being cut by chain sections. 


\section{REFERENCES}

1. Musijko V., Kuzminets M., 2007. Problemy stvorennja tehnologii ta tehniky dlia vykonannia zemlianyh robit pid chas kapital'nogo remontu promyslovyh truboprovidnyh magistralei. Girn., budiv., dor. ta melior. mashyny, Kyiv, Vol. 70, 56-64 (in Ukrainian).

2. Eugene Gorbatenko, Irina Bratasyuk, Vladimir Sharov, 2015. Mobile building is in coastal hydraulic engineering. Underwater Technologies, Vol.01, 22-32 (in Russian).

3. Nikolay Zhuk, Myron Nazarian, Yury Stelmakhov, 2015. "Great silk road": modern problems of reconstruction. Underwater Technologies, Vol.01, 59-64 (in Russian).

4. Volodymyr Gryshyn, Lev Gembarskyi, Volodymyr Snisarenko, 2015. Existing and projected artificial islands and their purpose. Underwater Technologies, Vol. 02, 32-39 (in Ukrainian).

5. Gennadiy Haiko, Petro Zakharchenko, 2016. Perspectives of tunnel passages construction under the Dnieper. Underwater Technologies, Vol.04, 72-79.

6. Kuzminets M., 2008. Stvorennja mashyny rozkryvannja truboprovodiv z nahylenym odna proty odnoi' sekcijamy robochogo organa. Visnyk NTU, Vyp.17, Ch.2, 26-32 (in Ukrainian).

7. Kuzminets M., 2011. Osoblyvosti robochyh procesiv zemleryjnyh mashyn $\mathrm{v}$ umovah blyz'ko roztashovanogo dijuchogo truboprovodu. Avtomobil'ni dorogy i transportne budivnyctvo, Vyp.81, 115-122 (in Ukrainian).

8. Olga Medvedeva, 2016. Determining the size of the suction Funnel for underwater placer mining technology. Underwater Technologies, Vol.03, 47-53 (in Russian).

9. Kuzminets M., Sivko V., 2010. Vybir racional'nyh parametriv robochyh organiv zemleryjnyh mashyn cherez robotu rujnuvannja g'runtovogo seredovyshha. Tehnika budivnyctva, Vol. 25, 121-128 (in Ukrainian).

10. Andrey Tevyashev, Olga Matviyenko, 2016. Estimation of the potential of resource and energy saving in the management of development and functioning of water main. Underwater Technologies, Vol. 04, 26-37 (in Russian).

11. Musijko V., Kuzminets M., 2011. Fizyczne modelarstwo roboczych procesów do kopania maszyn w warunkach blisko rozmieszczonego rurociągu. Metody Obliczeniowe i Badawcze w Rozwoju Pojazdow Samochodowych i Maszyn Roboczych Samojezdnych. Rzeszow, Politechnika Rzeszowska, SACON, 11, 95-100 (in Poland).

12. Sukach M., Lysak S., 2008. Pidvyshchennia efektyvnosti robochogo obladnannia mashyny dlia rozkryvannia truboprovodiv. Girn., budiv., dor. ta melior. mashyny. Kyiv, Vol.71, 3-9 (in Ukrainian).

13. Patent Ukrainy 37784, E02 F5/00, 2008. Zemleryine obladnannia transheiekopacha dlia rozkryvannia-zahlyblennia truboprovodiv. Sukach M., Lysak S., Opubl. 10.12.2008, Bjul.23, 6 (in Ukrainian).

14. Patent Ukrainy 42389, E02 F5/00, 2008. Transhejnyj ekskavator dlja rozkryvannja pidzemnyh truboprovodiv. Sukach M., Lysak S., Opubl. 10.07.2009, Bjul.13, 6 (in Ukrainian).

15. Harbuzov Z., Donskoi V., 1987. Ekskavatory nepreryvnogo deistviia. Moskwa, Vyssha shkola, 288 (in Russian).

16. Harbuzov Z. and oth., 1965. Zemleroinyie mashyny nepreryvnogo deistviia. Konstruktsii i raschety. Under the general editorship of L.Podborskiy. Moskow, Mashinostroienie, 234 (in Russian).

17. Sukach M., Lysak S., 2011. Optymizacija parametriv lancjugovogo robochogo organa transhejekopacha. 3 mizhnar. nauk.-prakt. konf. Suchasni informacijni ta innovacijni tehnologii na transport, Kherson, 20 (in Ukrainian).

\section{Кинематические параметры двухсекционного траншеекопателя}

\author{
Михаил Сукач, Сергей Лысак
}

Аннотация. Проведен кинематический анализ работы траншеекопателя, раскрывающего трубопровод по его периметру. Установлены зависимости между кинематическими и геометрическими параметрами рабочего оборудования.

Ключевые слова: кинематический анализ, траншеекопатель, трубопровод, рабочее оборудование. 